\title{
Effect of re-ensiling on the quality of sorghum silage
}

\author{
G. V. S. dos Anjos, ${ }^{* 1}$ L. C. Gonçalves, ${ }^{*}$ J. A. S. Rodrigues,† K. M. Keller,‡ M. M. Coelho, ${ }^{*}$ P. H. F. Michel, ${ }^{*}$ \\ D. Ottoni, ${ }^{*}$ and D. G. Jayme* \\ *Department of Animal Science, Veterinary School, Federal University of Minas Gerais, Minas Gerais, 31270-901, Brazil \\ †Brazilian Agricultural Research Corporation, EMBRAPA—Maize and Sorghum, Sete Lagoas, Minas Gerais, 35701-970, Brazil \\ ‡Department of Preventive Veterinary Medicine, Veterinary School, Federal University of Minas Gerais, Minas Gerais, 31270-901, Brazil
}

\section{ABSTRACT}

The commercialization of silage in many countries, including Brazil, has increased in recent years. Reensiling of previously ensiled forage occurs when silage is relocated from one farm to another, where it will be compacted and sealed again. During this process, silage is exposed to oxygen before being ensiled, which may affect its quality. We exposed sorghum silage to air during the anaerobic storage phase to simulate the transportation of silages between farms. Experimental treatments included silage exposed to air for 0 or $12 \mathrm{~h}$, with or without the use of an inoculant containing a mixture of Lactobacillus plantarum and the propionic bacteria Propionibacterium acidipropionici $\left(1 \times 10^{6} \mathrm{cfu} / \mathrm{g}\right.$ of forage; Biomax corn, Lallemand, Saint-Simon, France), totaling 4 treatments: conventional silage, conventional silage with inoculant use, re-ensilage after exposure to air, and re-ensilage after exposure to air with use of an inoculant. The sorghum was stored in experimental silos containing about $9.0 \mathrm{~kg}$ of fresh forage per replicate. Treatments were tested in a factorial $2 \times 2$ design with 5 replicates each. Chemical composition, in vitro dry matter digestibility, fermentative characteristics, losses (due to gas, effluents, and total dry matter), microorganism counts, and aerobic stability of sorghum silage were evaluated. Dry matter content of sorghum before ensiling was $273.12 \mathrm{~g} / \mathrm{kg}$. The 12 -h re-ensiling process increased the effluent loss of the silage when compared with conventional silage (456.42 vs. $201.19 \mathrm{~g} / \mathrm{kg}$ of FM, respectively). In addition, re-ensiled silages presented lower concentrations of lactic acid and higher concentrations of propionic acid than the silages that had not been opened during storage. The aerobic stability of silage was not affected by the re-ensiling process and the use of inoculant. The use of inoculant increased the

Received August 15, 2017.

Accepted February 21, 2018.

${ }^{1}$ Corresponding author: g.dosanjos@hotmail.com
$\mathrm{pH}$ and loss of dry matter of the silages (4.23 vs. 3.98 and 14.05 vs. $7.82 \%$, respectively) and therefore did not provide any benefits in this study.

Key words: aerobic stability, Propionibacterium acidipropionici, Lactobacillus plantarum, relocation, silage quality

\section{INTRODUCTION}

Forage conservation in the form of silage occurs under anaerobic conditions, where soluble carbohydrates are fermented to organic acids that reduce the $\mathrm{pH}$ of the medium, thus conserving the material by inhibiting the growth of undesirable microorganisms. When exposed to air, the silage may deteriorate and lose its nutritional value because of growth of detrimental microorganisms such as yeasts (Pahlow et al., 2003).

In Brazil, the commercialization of silage has become more frequent owing to reduced crop yields as a result of climatic variations during the rainy season and occurs mainly on small farms that do not have sufficient manpower and machinery for the production of silage. Additional factors associated with the decision to purchase silage from other farms include the excessive losses during storage and regional topography (de Lima et al., 2016). To meet the demands of this growing market, some farmers have started specializing in silage production for commercialization. As a result, forage ensiled on the farm must be unpacked and transported to other locations, where it will be compacted and sealed again. During this process, the material is exposed to air for an indeterminate period, which affects the quality of the silage (Michel et al., 2017). The existing literature on the re-ensiling process is very scarce and usually does not take into account the characteristics of the tropical climate. As a result, farmers and technicians are faced with numerous uncertainties regarding possible detrimental effects of silage transport.

Silage stability in the presence of oxygen is an important factor that determines the quality and nutritional value of this material (Filya et al., 2004), and bacterial 
inoculants may attenuate the decline in silage quality during the transportation process. The aim of this study was to evaluate the effect of re-ensiling and the use of microbial inoculants (Lactobacillus plantarum and Propionibacterium acidipropionici) on the quality of sorghum silage.

\section{MATERIALS AND METHODS}

\section{Planting, Harvesting, and Ensiling}

The BRS 655 sorghum crop was planted in November 2013 in the experimental area of Embrapa Milho e Sorgo, located in Sete Lagoas, Minas Gerais, Brazil $\left(19^{\circ} 28^{\prime} \mathrm{S}, 44^{\circ} 15^{\prime} \mathrm{W}\right.$, altitude $\left.732 \mathrm{~m}\right)$. Sorghum was planted in 5 blocks, each with $2,000 \mathrm{~m}^{2}$, to provide samples representing a range of moisture and soil fertility. The space between planting lines was $70 \mathrm{~cm}$. The crop was fertilized at planting $(32,112,64$, and $2 \mathrm{~kg} / \mathrm{ha}$ of $\mathrm{N}, \mathrm{P}$, $\mathrm{K}$, and Zn, respectively), and a top-dressing of $100 \mathrm{~kg}$ of $\mathrm{N} /$ ha was applied $35 \mathrm{~d}$ after planting.

When the grain reached the milk stage, the crop was harvested and chopped into 1-to-2-cm segments with a conventional forage harvester (JF C120 AT; JF Agricultural Machines, Itapira, Brazil). The chopped forage was sampled (1 sample of $800 \mathrm{~g} /$ block) and analyzed before being inoculated. Half of the material harvested in each block was weighed and inoculated; the other half was weighed and water was added at a rate identical to that of the inoculated silage $(200 \mathrm{~mL}$ for $100 \mathrm{~kg}$ of fresh forage). A total of $9.0 \pm 0.1 \mathrm{~kg}$ of sorghum was placed in each silo, and the forage was then manually compacted into experimental silos. For each block, a silo was made for each of the 4 treatments, amounting to 20 experimental silos in total. Silos were made from 20-L plastic buckets equipped with a Bunsen valve to allow for the release of fermentation gas. A cotton bag was placed inside each bucket with approximately $2 \mathrm{~kg}$ of dry sand to allow the measurement of effluent.

\section{Experimental Design}

The re-ensiling process and the use of a microbial inoculant during ensiling and re-ensiling of silage after $12 \mathrm{~h}$ of air exposure were evaluated, and $12 \mathrm{~h}$ was considered to be the minimum time required for ensiling and re-ensiling processes in Brazil. The treatments were arranged in a $2 \times 2$ factorial scheme, with 5 replicates each (blocks). The first variable examined was the re-ensiling process (with or without), and the second variable investigated was the use of inoculant (used or not used).

The inoculum comprised the facultative heterofermentative lactic acid bacteria L. plantarum MA18/5U and the propionic bacteria P. acidipropionici MA26/4U (Biomax corn, Lallemand, Saint-Simon, France). Inoculation $\left(1 \times 10^{6} \mathrm{cfu} / \mathrm{g}\right.$ of forage $)$ was performed at ensiling. The inoculum was diluted in water and was uniformly sprayed onto the forage with a backpack sprayer and mixed.

Fifty-six days after ensiling, half of the silos were opened and re-ensiled. The silos were opened in a shed, and the material was removed and re-ensiled after $12 \mathrm{~h}$ of air exposure. The temperature ranged between 20.0 and $26.0^{\circ} \mathrm{C}$ during the exposure period, and relative humidity was between 61 and $92 \%$ (data obtained from the automatic weather station of the Brazilian National Institute of Meteorology, located $2.4 \mathrm{~km}$ from the shed).

All silos were opened $240 \mathrm{~d}$ after the re-ensiling process (296 d of storage in total). Samples were obtained for analysis of chemical composition, in vitro digestibility, silage quality $\left(\mathrm{pH}, \mathrm{NH}_{3}-\mathrm{N}\right.$, and lactic, acetic, propionic, and butyric acids), loss of material (gas, effluent, and total DM), aerobic stability, and total count of molds, yeasts, and aerobic bacteria.

\section{Chemical Analysis and In Vitro DM Digestibility}

Fresh forage samples were oven-dried at $55^{\circ} \mathrm{C}$ for $72 \mathrm{~h}$ and were subsequently processed in a knife mill (sieve size $=1 \mathrm{~mm}$; Thomas Wiley model 4 , Thomas Scientific, Swedesboro, NJ). Dry matter at $105^{\circ} \mathrm{C}, \mathrm{CP}$, ash, and ether extract (EE) were determined according to procedures outlined by AOAC International (2005).

Cell wall components (NDF, ADF, and lignin) were determined by the sequential method according to methods described by Van Soest et al. (1991). The NDF and ADF residues were subjected to ash and CP analyses to determine the amount of neutral detergent insoluble protein and acid detergent insoluble protein. These values were used to correct NDF and ADF for ash and protein. The NFC levels were calculated using the equation proposed by NRC (2001); NFC = $100-(\% \mathrm{NDF}+\% \mathrm{CP}+\% \mathrm{EE}+\mathrm{MM})$, where MM is the amount of mineral matter or ash. In vitro DM digestibility (IVDMD) was determined on the DaisyII digestion apparatus (Ankom Technology, Fairport, NY) according to methods described by Tilley and Terry (1963) and adapted by Holden (1999). Ruminal fluid was collected from a cannulated cow that was fed a diet comprising $10 \mathrm{~kg}(\mathrm{DM})$ of sorghum silage and $3 \mathrm{~kg}$ (DM) of commercial concentrate.

\section{Analysis of Fermentative Parameters}

Silage juice was extracted by a hydraulic press $(2.5$ $\mathrm{kgf} / \mathrm{cm}^{2}$ ) to determine the $\mathrm{pH}$, ammoniacal nitrogen 
$\left(\mathrm{NH}_{3}-\mathrm{N}\right)$, and organic acids. The $\mathrm{pH}$ was measured with a digital potentiometer (HI 221, Hanna Instruments, Woonsocket, RI). Distillation to determine $\mathrm{NH}_{3}-\mathrm{N}$ was performed in Kjeldahl equipment using magnesium oxide and calcium chloride as a neutralizing medium for the evaporation of ammonia, with boric acid as the receptor solution and $0.1 M$ hydrochloric acid as the titrant. The levels of organic acids (acetic, lactic, propionic, and butyric acid) were determined by GC (GC-17 Shimadzu gas chromatograph; Shimadzu Corp., Kyoto, Japan) equipped with a flame ionization detector and fitted with a Kukol capillary column according to the methodology described by Playne (1985). The gas chromatograph was operated isothermally with a column temperature of $200^{\circ} \mathrm{C}$ and an inlet and detector temperature of $225^{\circ} \mathrm{C}$. The $\mathrm{pH}$ values of samples subjected to the aerobic stability test were determined as follows: fresh silage $(9 \mathrm{~g})$ was added to $60 \mathrm{~mL}$ of distilled water, and $\mathrm{pH}$ values were measured after $30 \mathrm{~min}$ (Silva and Queiroz, 2002).

\section{Analysis of Loss}

The weight of the empty silos plus lid plus dry sand bags was recorded before the ensiling process. The silos were then filled with forage, compacted, covered, sealed with adhesive tape, and weighed again.

Silos subjected to the re-ensiling procedure were opened at $56 \mathrm{~d}$ and weighed before and after forage removal to determine the production of gases and effluents. The DM content in the forage was also determined. The sand deposited at the bottom of each silo was replaced, after which the empty set was weighed. The forage was re-ensiled after $12 \mathrm{~h}$ of air exposure. After filling and sealing, the experimental silos were weighed again to determine the total weight.

We weighed all silos $296 \mathrm{~d}$ after the initial ensiling to determine the loss of gas. Silages were then removed, and the silos were weighed to quantify the effluent produced. Total DM loss was estimated as the difference between the final and initial dry weight of the experimental silos in relation to silage DM weight, minus the weight of the ensilage set before the silos were opened (Jobim et al., 2007). Gas, effluent, and total DM losses for the re-ensiled silages were obtained from the sum of losses during the opening for re-ensiling and the final opening.

\section{Aerobic Stability Test}

Plastic buckets $(23 \mathrm{~cm}$ height and $66 \mathrm{~cm}$ circumference) containing $1.5 \mathrm{~kg}$ of silage per replicate were placed in a room at $25 \pm 1{ }^{\circ} \mathrm{C}$ to evaluate aerobic stability. Silage temperature was monitored every $10 \mathrm{~min}$ with the aid of a temperature data logger inserted $15 \mathrm{~cm}$ into the center of mass. In addition, $1.5 \mathrm{~kg}$ of silage was placed in another set of buckets to track changes in microbial and $\mathrm{pH}$ counts. Samples from these buckets were taken on d $0,2,6$, and 10 following the opening of silos for $\mathrm{pH}$ evaluation. Aerobic deterioration was considered to have occurred if the temperature difference between the materials and ambience reached $2^{\circ} \mathrm{C}$ (Ranjit and Kung, 2000). Microorganisms were counted in silage samples on $\mathrm{d} 0$ and when they lost aerobic stability or on d 10 in silages that remained stable.

\section{Microbiological Analyses}

Samples were collected for total aerobic microbial counts (yeasts, mold, and aerobic bacteria). Analysis of the microbiota was performed using a standard dispersion plate method. Total bacterial counts were determined aerobically on plate count agar (Difco, Sparks, MD) following an incubation period of 1 to $3 \mathrm{~d}$ at 36 $\pm 1^{\circ} \mathrm{C}$. Total yeast counts were determined on tryptone glucose yeast extract agar according to Pitt and Hocking (2009). Next, aerobic samples were incubated for 1 to $3 \mathrm{~d}$ at $30 \pm 1^{\circ} \mathrm{C}$. Total mold count was determined on dichloran rose-bengal chloramphenicol agar according to Pitt and Hocking (2009) after an aerobic incubation period of 5 to $7 \mathrm{~d}$ at $25 \pm 1^{\circ} \mathrm{C}$. The plates were examined daily for typical colony and morphological characteristics associated with each growth medium. Total microbial counts were expressed as colony forming units per gram. All microbial counts were $\log _{10}$ transformed to obtain lognormal distribution.

\section{Statistical Analyses}

The results of chemical composition, in vitro digestibility, silage quality, losses, aerobic stability, and total counts of molds, yeasts, and aerobic bacteria were analyzed in randomized blocks in a $2 \times 2$ factorial scheme with 5 replicates. Analyses were carried out as follows:

$$
\mathrm{Y}_{\mathrm{ijk}}=\mu+\mathrm{R}_{\mathrm{i}}+\mathrm{I}_{\mathrm{j}}+\mathrm{N}_{\mathrm{ij}}+\mathrm{B}_{\mathrm{k}}+\mathrm{e}_{\mathrm{ijk}}
$$

where $\mathrm{Y}_{\mathrm{ijk}}=$ observed response values; $\mu=$ overall mean; $\mathrm{R}_{\mathrm{i}}=$ the effect of the ith level of re-ensiling time $(0$ or $12 \mathrm{~h}) ; \mathrm{I}_{\mathrm{j}}=$ the effect of the jth level of inoculant (with or without application); $\mathrm{N}_{\mathrm{ij}}=$ the effect of ith reensiling and jth inoculant interaction; $\mathrm{B}_{\mathrm{k}}=$ fixed effect of the kth block $(1,2,3,4,5)$; and $\mathrm{e}_{\mathrm{ijk}}=$ random error. 
The $\mathrm{pH}$ data on $\mathrm{d} 0,2,6$, and 10 of the aerobic stability test were analyzed in randomized blocks with subdivided plots. The sources of variation were blocks, treatments in $2 \times 2$ factorial arrangement (plots), and days of evaluation (subplots). Analyses were carried out as follows:

$$
\begin{aligned}
\mathrm{Y}_{\mathrm{ijk}}=\mu+ & \mathrm{R}_{\mathrm{i}}+\mathrm{I}_{\mathrm{j}}+\mathrm{D}_{1}+\mathrm{N}_{\mathrm{ij}}+\mathrm{O}_{\mathrm{il}}+\mathrm{P}_{\mathrm{jl}} \\
& +\mathrm{Q}_{\mathrm{ijl}}+\mathrm{B}_{\mathrm{k}}+\mathrm{e}_{\mathrm{ijk}},
\end{aligned}
$$

where $Y_{\mathrm{ijk}}=$ observed response values; $\mu=$ overall mean; $\mathrm{R}_{\mathrm{i}}=$ the effect of the ith level of re-ensiling time (0 or $12 \mathrm{~h}) ; \mathrm{I}_{\mathrm{j}}=$ the effect of the jth level of inoculant (with or without application); $\mathrm{D}_{1}=$ the fixed effect of the lth days of evaluation $(0,2,6$, and 10$) ; \mathrm{N}_{\mathrm{ij}}=$ the effect of the ith re-ensiling and jth inoculant interaction; $\mathrm{O}_{\mathrm{il}}=$ interaction between the ith re-ensiling and lth days of evaluation; $\mathrm{P}_{\mathrm{jl}}=$ interaction between the jth inoculant and lth days of evaluation; $\mathrm{Q}_{\mathrm{ijl}}=$ the interaction between the ith re-ensiling time, the jth inoculant present, and the lth days of evaluation; $B_{k}=$ fixed effect of the kth block $(1,2,3,4,5)$; and $\mathrm{e}_{\mathrm{ijk}}=$ random error.

Data were submitted to ANOVA. When significant interactions were identified, further analyses of simple effects were conducted (sliced ANOVA). When interactions were found to be insignificant, the effects of the re-ensiling process and inoculation were analyzed separately by $F$-tests at $5 \%$ significance. Regression analysis at $5 \%$ significance was carried out to examine the effect of days of evaluation on silage $\mathrm{pH}$ during the aerobic stability test. The analysis was performed using the PROC GLM software from SAS (SAS Institute Inc., Cary, NC).

\section{RESULTS AND DISCUSSION}

The process of re-ensiling has been adopted as a common practice for Brazilian farmers in recent years. Once exposed to oxygen, the ensiled material can be stored for several months after re-ensiling. Most farmers use the re-ensiled material within a short time (approximately $60 \mathrm{~d}$ or less). However, many farmers purchase large amounts of silage at low prices and re-ensile the silage for use throughout the year. Thus, aiming to simulate scenarios like this, we decided to keep the stored re-ensiled material for $240 \mathrm{~d}$.

Our results demonstrated that re-ensiling sorghum silage did not significantly affect silage quality. In addition, the use of microbial inoculant containing L. plantarum and P. acidipropionici did not cause improvements in the silages.
The DM content of the fresh sorghum before ensiling and inoculation was $273.12 \mathrm{~g} / \mathrm{kg}$; the sorghum contained $66.5 \mathrm{~g} / \mathrm{kg}$ of DM CP, $42.1 \mathrm{~g} / \mathrm{kg}$ of DM ash, 23.7 $\mathrm{g} / \mathrm{kg}$ of DM EE, $558.7 \mathrm{~g} / \mathrm{kg}$ of DM NDF, $301.9 \mathrm{~g} / \mathrm{kg}$ of DM ADF, and $47.93 \mathrm{~g} / \mathrm{kg}$ of DM lignin. The chemical composition of the re-ensilaged silages did not present alterations regarding the conventional silages (Table 1 ). Silages exposed to air deteriorate as a result of aerobic microbial activity, leading to loss of nutritional value (Filya et al., 2006). However, the deterioration process depends on the quality of the ensiled material and the air exposure time (Chen and Weinberg, 2014; de Lima et al., 2016).

Silages inoculated with microbial additives exhibited higher levels of neutral detergent insoluble protein compared with noninoculated silages (23.3 vs. $20.2 \mathrm{~g} /$ $\mathrm{kg}$ of $\mathrm{DM})$. In addition, NDF values were higher in inoculated silage materials. Furthermore, inoculated silages demonstrated lower NFC content compared with untreated silages. Filya et al. (2000) also reported lower NFC content in silages inoculated with microbial additives than in noninoculated silages. According to the authors, lower NFC contents represent a greater extent of silage fermentation.

The success of an introduced inoculant depends on several factors, such as the properties of plants and inoculants used (Kristensen et al., 2010; Muck, 2010). It was observed that the use of inoculant led to a decrease in silage quality (decreased NFC and IVDMD). Because NFC are highly digestible organic compounds, their reduction in concentration may result in reduced digestibility of the material (McDonald and Heron, 2001), as observed in silages that received microbial inoculants (Table 1). There was no difference in IVDMD between conventional and re-ensiled silages. The use of microbial inoculants resulted in a $3 \%$ reduction in IVDMD compared with noninoculated silages (616.6 vs. $635.2 \mathrm{~g} / \mathrm{kg}$ of DM).

Table 2 outlines measurements of fermentation parameters. Results indicated that re-ensiling reduced the $\mathrm{NH}_{3}-\mathrm{N}$ content of the material. In addition, re-ensiled materials had lower lactic acid and higher propionic acid contents compared with conventional silages (29.0 vs. 46.7 and 8.7 vs. $2.7 \mathrm{~g} / \mathrm{kg}$ of DM, respectively). This was expected, as exposure of silage to air enables the growth of deteriorating aerobic microorganisms such as molds, yeasts, and certain bacteria, which can use VFA for metabolism. One of the main products consumed by yeasts is lactic acid, producing $\mathrm{CO}_{2}$ and water in the process (Tabacco et al., 2011).

The use of inoculant increased silage $\mathrm{pH}$, reduced lactic acid content of the material, and increased propionic acid concentration. It has been shown that in addition 
Table 1. Chemical composition $(\mathrm{g} / \mathrm{kg}$ of $\mathrm{DM})$ of sorghum silage treated with inoculants and after re-ensiling

\begin{tabular}{|c|c|c|c|c|c|c|c|c|}
\hline \multirow[b]{3}{*}{ Parameter $^{1}$} & \multicolumn{4}{|c|}{ Treatment $^{2}$} & \multirow[b]{3}{*}{ SEM } & \multirow{2}{*}{\multicolumn{3}{|c|}{$P$-value ${ }^{3}$}} \\
\hline & \multicolumn{2}{|c|}{ Control } & \multicolumn{2}{|c|}{ Inoculant } & & & & \\
\hline & SIL & $\mathrm{RE}$ & SIL & $\mathrm{RE}$ & & I & $\mathrm{R}$ & $\mathrm{I} \times \mathrm{R}$ \\
\hline DM & 263.9 & 264.3 & 245.8 & 259.2 & 3.70 & NS & NS & NS \\
\hline Ash & 41.8 & 45.1 & 46.6 & 43.7 & 0.76 & NS & NS & $<0.05$ \\
\hline $\mathrm{CP}$ & 83.2 & 90.2 & 84.6 & 91.7 & 1.67 & NS & NS & NS \\
\hline NDIP & 18.9 & 21.6 & 23.9 & 22.7 & 0.62 & $<0.05$ & NS & NS \\
\hline ADIP & 12.9 & 13.8 & 13.5 & 13.1 & 0.28 & NS & NS & NS \\
\hline $\mathrm{EE}$ & 27.7 & 24.5 & 25.8 & 25.4 & 0.84 & NS & NS & NS \\
\hline NDF & 600.7 & 619.5 & 634.0 & 648.9 & 6.55 & $<0.01$ & NS & NS \\
\hline NDFap & 568.4 & 584.5 & 613.2 & 611.7 & 7.32 & $<0.01$ & NS & NS \\
\hline $\mathrm{ADF}$ & 337.9 & 334.0 & 325.4 & 349.0 & 5.44 & NS & NS & NS \\
\hline ADFap & 324.3 & 318.9 & 310.9 & 334.8 & 5.42 & NS & NS & $<0.05$ \\
\hline $\mathrm{NFC}$ & 246.7 & 220.6 & 202.6 & 190.3 & 7.15 & $<0.01$ & NS & NS \\
\hline Lignin & 40.9 & 37.9 & 37.9 & 38.5 & 0.98 & NS & NS & NS \\
\hline IVDMD & 636.8 & 633.5 & 628.3 & 604.8 & 5.23 & $<0.05$ & NS & NS \\
\hline
\end{tabular}

${ }^{1} \mathrm{NDIP}=$ neutral detergent insoluble protein; ADIP $=$ acid detergent insoluble protein; $\mathrm{EE}=$ ether extract; NDFap $=$ neutral detergent insoluble fiber corrected for ash and protein; ADFap $=$ acid detergent insoluble fiber corrected for ash and protein; IVDMD = in vitro DM digestibility.

${ }^{2}$ Experimental treatments included silage exposed to air for 0 or $12 \mathrm{~h}$ with or without the use of an inoculant containing a mixture of Lactobacillus plantarum and the propionic bacteria Propionibacterium acidipropionici $\left(1 \times 10^{6} \mathrm{cfu} / \mathrm{g}\right.$ of forage; Biomax corn, Lallemand, Saint-Simon, France), totaling 4 treatments: conventional silage (SIL), conventional silage with inoculant use, re-ensilage (RE) after exposure to air, and re-ensilage after exposure to air with inoculant use.

${ }^{3} \mathrm{I}=$ inoculant effect; $\mathrm{R}=$ re-ensiling effect; $\mathrm{I} \times \mathrm{R}=$ interaction effect.

to carbohydrates, $P$. acidipropionici uses lactic acid as substrates during the fermentation process (Filya et al., 2004). It is possible that in this study, the use of inoculant promoted the reduction of lactic acid and an increase of propionic acid compared with untreated silages.
Silo fermentation produces volatile compounds that may lead to DM reduction in the ensiled material (Kristensen et al., 2010). The re-ensiled silages showed higher losses due to effluent compared with conventional silages (456 vs. $210 \mathrm{~g} / \mathrm{kg}$, respectively; Table 2). According to Michel et al. (2017), the higher effluent

Table 2. Fermentation quality parameters ( $\mathrm{g} / \mathrm{kg}$ of DM unless noted) of sorghum silage after re-ensiling and treatment with inoculants

\begin{tabular}{|c|c|c|c|c|c|c|c|c|}
\hline \multirow[b]{3}{*}{ Parameter ${ }^{1}$} & \multicolumn{4}{|c|}{ Treatment $^{2}$} & \multirow[b]{3}{*}{ SEM } & \multirow{2}{*}{\multicolumn{3}{|c|}{$P$-value ${ }^{3}$}} \\
\hline & \multicolumn{2}{|c|}{ Control } & \multicolumn{2}{|c|}{ Inoculant } & & & & \\
\hline & SIL & $\mathrm{RE}$ & SIL & $\mathrm{RE}$ & & I & $\mathrm{R}$ & $\mathrm{I} \times \mathrm{R}$ \\
\hline$\overline{\mathrm{pH}}$ & 3.98 & 3.98 & 4.05 & 4.42 & 0.07 & $<0.01$ & NS & NS \\
\hline $\mathrm{NH}_{3}-\mathrm{N} / \mathrm{TN}(\mathrm{g} / \mathrm{kg})$ & 31.5 & 25.7 & 34.9 & 28.0 & 0.14 & NS & $<0.05$ & NS \\
\hline Lactic acid & 75.65 & 42.74 & 17.82 & 15.23 & 7.03 & $<0.01$ & $<0.05$ & NS \\
\hline Acetic acid & 11.66 & 38.45 & 29.91 & 30.38 & 4.60 & NS & NS & NS \\
\hline Propionic acid & 1.46 & 4.68 & 3.97 & 12.78 & 1.43 & $<0.05$ & $<0.01$ & NS \\
\hline Butyric acid & 4.15 & 1.14 & 7.20 & 7.17 & 1.09 & NS & NS & NS \\
\hline Gas loss (\% of DM) & 5.47 & 6.37 & 11.08 & 12.55 & 1.13 & $<0.05$ & NS & NS \\
\hline Effluent loss ( $\mathrm{g} / \mathrm{kg}$ of $\mathrm{FM})$ & 184.64 & 415.97 & 235.74 & 496.86 & 30.51 & $<0.01$ & $<0.01$ & NS \\
\hline Total loss (\% of DM) & 6.60 & 9.04 & 14.21 & 13.90 & 1.37 & $<0.05$ & NS & NS \\
\hline
\end{tabular}

${ }^{1} \mathrm{NH}_{3}=$ ammonia nitrogen; $\mathrm{TN}=$ total nitrogen; $\mathrm{FM}=$ fresh matter.

${ }^{2}$ Experimental treatments included silage exposed to air for 0 or $12 \mathrm{~h}$ with or without the use of an inoculant containing a mixture of Lactobacillus plantarum and the propionic bacteria Propionibacterium acidipropionici $\left(1 \times 10^{6} \mathrm{cfu} / \mathrm{g}\right.$ of forage; Biomax corn, Lallemand, Saint-Simon, France), totaling 4 treatments: conventional silage (SIL), conventional silage with inoculant use, re-ensilage (RE) after exposure to air, and re-ensilage after exposure to air with inoculant use.

${ }^{3} \mathrm{I}=$ inoculant effect; $\mathrm{R}=$ re-ensiling effect; $\mathrm{I} \times \mathrm{R}=$ interaction effect. 
Table 3. Aerobic stability (h) and microbial total count (log10 cfu/g) under various conditions

\begin{tabular}{|c|c|c|c|c|c|c|c|c|}
\hline \multirow[b]{3}{*}{ Parameter } & \multicolumn{4}{|c|}{ Treatment $^{1}$} & \multirow[b]{3}{*}{ SEM } & & & \\
\hline & \multicolumn{2}{|c|}{ Control } & \multicolumn{2}{|c|}{ Inoculant } & & \multicolumn{3}{|c|}{$P$-value ${ }^{2}$} \\
\hline & SIL & $\mathrm{RE}$ & SIL & $\mathrm{RE}$ & & I & $\mathrm{R}$ & $\mathrm{I} \times \mathrm{R}$ \\
\hline Aerobic stability & 240 & 225.6 & 240 & 206.4 & 8.49 & NS & NS & NS \\
\hline \multicolumn{9}{|l|}{ Microbial count at silage opening } \\
\hline Aerobic bacteria & 5.40 & 5.82 & 6.04 & 5.69 & 0.15 & NS & NS & NS \\
\hline Yeasts & 2.89 & 2.53 & 3.11 & 3.09 & 0.17 & NS & NS & NS \\
\hline Molds & 2.90 & 2.54 & 2.25 & 3.02 & 0.18 & NS & NS & NS \\
\hline \multicolumn{9}{|l|}{ Count at loss of stability } \\
\hline Aerobic bacteria & 5.86 & 6.92 & 6.09 & 5.45 & 0.18 & NS & NS & NS \\
\hline Yeasts & 5.76 & 6.03 & 1.99 & 2.15 & 0.54 & $<0.05$ & NS & NS \\
\hline Molds & 4.01 & 6.31 & 3.88 & 2.14 & 0.43 & NS & NS & NS \\
\hline
\end{tabular}

${ }^{1}$ Experimental treatments included silage exposed to air for 0 or $12 \mathrm{~h}$ with or without the use of an inoculant containing a mixture of Lactobacillus plantarum and the propionic bacteria Propionibacterium acidipropionici $\left(1 \times 10^{6} \mathrm{cfu} / \mathrm{g}\right.$ of forage; Biomax corn, Lallemand, Saint-Simon, France), totaling 4 treatments: conventional silage (SIL), conventional silage with inoculant use, re-ensilage (RE) after exposure to air, and re-ensilage after exposure to air with inoculant use.

${ }^{2} \mathrm{I}=$ inoculant effect; $\mathrm{R}=$ re-ensiling effect; $\mathrm{I} \times \mathrm{R}=$ interaction effect.

losses in re-ensiled silages may be related to the fact that this material undergoes 2 compaction processes because the compaction allows the removal of water from the plant cells and thus promotes greater effluent production. However, no differences in total DM losses were detected between the 2 treatments. Similarly, Chen and Weinberg (2014) also did not detect any difference in DM loss of re-ensiled corn silage with up to $48 \mathrm{~h}$ of air exposure. Our results indicated that inoculated silages showed higher effluent and gas production losses compared with noninoculated silages (366 vs. 300 and 11.8 vs. $5.9 \mathrm{~g} / \mathrm{kg}$, respectively). Dry matter losses in silages inoculated with microbial additives were 6 percentage units higher compared with noninoculated silages (14.05 vs. $7.82 \%)$. Similarly, Tabacco et al. (2011) also reported higher DM losses in silages inoculated with microbial additives compared with those in conventional silages.

The aerobic stability of silage was not affected by the re-ensiling process and the use of inoculant (Table $3)$. During the course of the stability test $(240 \mathrm{~h})$, the temperature of the material remained relatively stable (mean temperature of the silages at the end of the test was $24.6^{\circ} \mathrm{C}$ ), which indicated maintenance of aerobic stability. This indicates that exposure of the silage to air for a period of $12 \mathrm{~h}$ did not promote changes that compromised the aerobic stability of the material, which was also evidenced by the similar microorganism count among all treatments at silo opening (Table 3). The $\mathrm{pH}$ of the silage during the re-ensiling process is an important factor for the success of the operation because some microorganisms deteriorating the silage, such as molds, do not develop in an acidic environment
(Muck, 2010), and even some microorganisms that may develop, as is the case of yeasts, have their limited growth rate under these conditions (Pitt and Muck, 1993).

On the other hand, although microorganism counts were similar at silo opening (Table 3 ), inoculated silages demonstrated lower yeast count compared with untreated silages following the stability test (2.07 vs. $5.89 \log \mathrm{cfu} / \mathrm{g}$ ). This may be due to higher production of propionic acid in inoculated silage, which acts as an important inhibitor of yeast growth (Filya et al., 2004). Tabacco et al. (2009) reported that yeast counts above $5 \log 10 \mathrm{cfu} / \mathrm{g}$ may reduce silage aerobic stability. However, the high yeast counts observed in the present study did not have an effect on silage stability.

During the aerobic stability test, an increase in $\mathrm{pH}$ was observed with increased air exposure time for all treatments (Figure 1). At silo opening, yeasts that use lactic acid under aerobic conditions may develop, thereby raising silage $\mathrm{pH}$ (Muck, 2010). An increase in $\mathrm{pH}$ values with greater air exposure was observed across all treatments. However, this increase was higher in silages inoculated with microbial additives (Figure 2 ). The $\mathrm{pH}$ increase in the inoculated silages during the aerobic stability test was not related to the higher yeast growth because the inoculated silages presented the lowest yeast counts at the end of the test. Inoculated silages had a higher $\mathrm{pH}$ from the opening of the silo and consequently a higher $\mathrm{pH}$ at the end of the stability test. However, when we observe Figure 2, the $\mathrm{pH}$ pattern is very similar between inoculated and noninoculated silages. The expected behavior would be an increase in yeast counts under low-pH (3.5-4.0) aerobic 


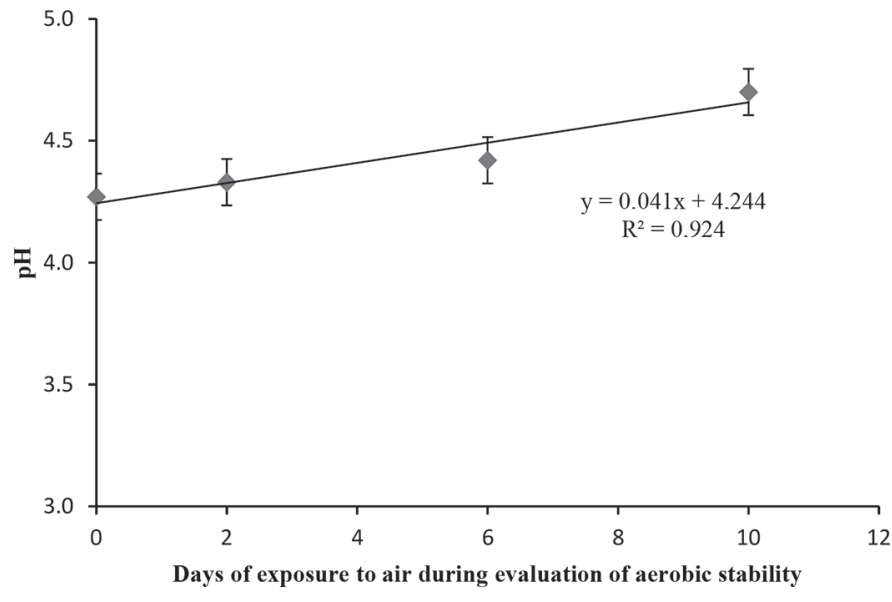

Figure 1. Changes in $\mathrm{pH}$ and SEM during air exposure during evaluation of aerobic stability. Average of all treatments.

conditions. In our experiment, the $\mathrm{pH}$ of the inoculated silages was 4.4, so other aerobic microorganisms may have been favored. Thus, the lower yeast count can be explained by lower growth rate in relation to aerobic bacteria (Muck, 2010). Although the aerobic bacteria count did not show statistical differences, counts were high in all treatments.

Overall, our results agree with the few studies on re-ensiling published so far (Chen and Weinberg, 2014; de Lima et al., 2016; Michel et al., 2017) that the re-ensiling process does not significantly affect silage quality. However, it is important that aspects such as the quality of the silage to be relocated are taken into account so that the risks of loss in the process are minimized.

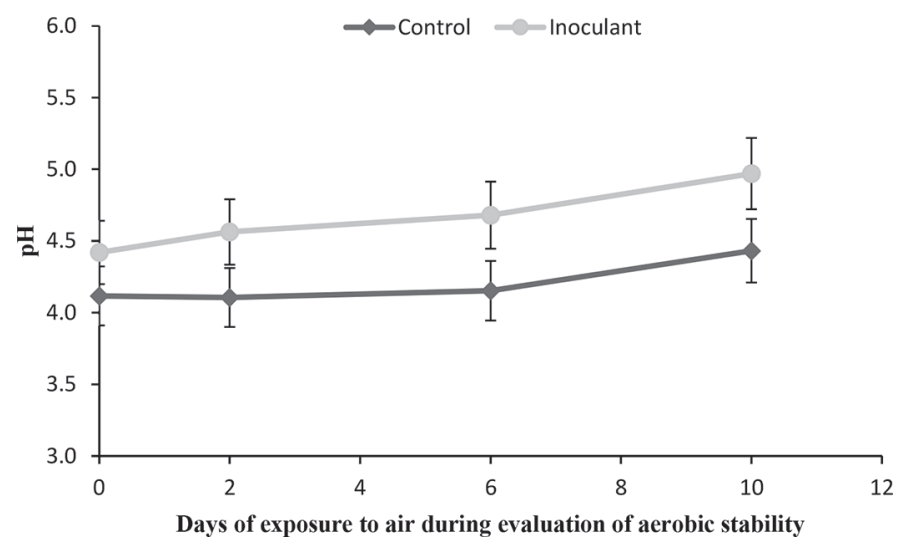

Figure 2. Changes in $\mathrm{pH}$ and SEM of silages with and without inoculant.

\section{CONCLUSIONS}

Re-ensiling after $12 \mathrm{~h}$ of aerobic exposure followed by $240 \mathrm{~d}$ of anaerobic storage did not lead to reduced nutritional quality or loss of aerobic stability compared with silages that remained sealed throughout storage. In our study, the inoculant did not contribute measurably to the success of the re-ensiling process.

\section{ACKNOWLEDGMENTS}

The authors thank the Brazilian Agricultural Research Corporation (EMBRAPA)-Maize and Sorghum, Sete Lagoas, Minas Gerais, Brazil, the Coordination and Improvement of Higher Level or Education Personnel (CAPES), the Veterinary School of Federal University of Minas Gerais (EVUFMG), and the Pro-Rector of Research of Federal University of Minas Gerais (PRPqUFMG), Belo Horizonte, Minas Gerais, Brazil, for their support and assistance.

\section{REFERENCES}

AOAC International. 2005. Official Methods of Analysis. 18th ed. AOAC International, Gaithersburg, MD.

Chen, Y., and Z. G. Weinberg. 2014. The effect of relocation of wholecrop wheat and corn silages on their quality. J. Dairy Sci. 97:406410.

de Lima, E. M., L. C. Gonçalves, K. M. Keller, J. A. dos Santos Rodrigues, F. P. C. Santos, P. H. F. Michel, V. S. Raposo, and D. G. Jayme. 2016. Re-ensiling and its effects on chemical composition, in vitro digestibility, and quality of corn silage after different lengths of exposure to air. Can. J. Anim. Sci. 97:250-257.

Filya, I., G. Ashbell, Y. Hen, and Z. G. Weinberg. 2000. The effect of bacterial inoculants on the fermentation and aerobic stability of whole crop wheat silage. Anim. Feed Sci. Technol. 88:39-46.

Filya, I., E. Sucu, and A. Karabulut. 2004. The effect of Propionibacterium acidipropionici, with or without Lactobacillus plantarum, on the fermentation and aerobic stability of wheat, sorghum and maize silages. J. Appl. Microbiol. 97:818-826.

Filya, I., E. Sucu, and A. Karabulut. 2006. The effects of Propionibacterium acidipropionici and Lactobacillus plantarum, applied at ensiling, on the fermentation and aerobic stability of low dry matter corn and sorghum silages. J. Ind. Microbiol. Biotechnol. 33:353-358.

Holden, L. A. 1999. Comparison of methods of in vitro dry matter digestibility for ten feeds. J. Dairy Sci. 82:1791-1794.

Jobim, C. C., L. G. Nussio, R. A. Reis, and P. Schmidt. 2007. Methodological advances in evaluation of preserved forage quality. Rev. Bras. Zootec. 36:101-119.

Kristensen, N. B., K. H. Sloth, O. Højberg, N. H. Spliid, C. Jensesn, and R. Thøgersen. 2010. Effects of microbial inoculants on corn silage fermentation, microbial contents, aerobic stability, and milk production under field conditions. J. Dairy Sci. 93:3764-3774.

McDonald, P. A. R. H., and S. J. E. Heron. 1991. The Biochemistry of Silage. 2nd ed. Chalcombe, Bucks, UK.

Michel, P. H. F., L. C. Gonçalves, J. A. S. Rodrigues, K. M. Keller, V. S. Raposo, E. M. Lima, F. P. C. Santos, and D. G. Jayme. 2017. Re-ensiling and inoculant application with Lactobacillus plantarum and Propionobacterium acidipropionic on sorghum silages. Grass Forage Sci. 72:432-440.

Muck, R. E. 2010. Silage microbiology and its control through additives. Rev. Bras. Zootec. 39:183-191. 
National Research Council. 2001. Nutrient Requirements of Dairy Cattle. 7th rev. ed. Natl. Acad. Press, Washington, DC.

Pahlow, G., R. E. Muck, F. Driehuis, S. J. W. H. Oude Elferink, and S. F. Spoelstra. 2003. Microbiology. Pages 31-93 in Silage Science and Technology, Agronomy Monograph 42. D. R. Buxton, R. E. Muck, and J. H. Harrison, ed. American Society of Agronomy, Madison, WI.

Pitt, J. I., and A. D. Hocking. 2009. Fungi and Food Spoilage. 3rd ed. Springer, New York, NY.

Pitt, R. E., and R. E. Muck. 1993. A diffusion model of aerobic deterioration at the exposed face of bunker silos. J. Agric. Eng. Res. $55: 11-26$

Playne, M. J. 1985. Determination of ethanol, volatile fatty acids, lactic and succinic acids in fermentation liquids by gas chromatography. J. Sci. Food Agric. 36:638-644.

Ranjit, N. K., and L. Kung Jr. 2000. The effect of Lactobacillus buchneri, Lactobacillus plantarum, or a chemical preservative on the fermentation and aerobic stability of corn silage. J. Dairy Sci. 83:526-535.
Silva, D. J., and A. C. Queiroz. 2002. Análise de Alimentos (Métodos Químicos e Biológicos). 3rd ed. UFV, Viçosa, MG, Brazil.

Tabacco, E., S. Piano, L. Cavallarin, T. F. Bernardes, and G. Borreani. 2009. Clostridia spore formation during aerobic deterioration of maize and sorghum silages as influenced by Lactobacillus buchneri and Lactobacillus plantarum inoculants. J. Appl. Microbiol. 107:1632-1641.

Tabacco, E., F. Righi, A. Quarantelli, and G. Borreani. 2011. Dry matter and nutritional losses during aerobic deterioration of corn and sorghum silages as influenced by different lactic acid bacteria inocula. J. Dairy Sci. 94:1409-1419.

Tilley, J. M. A., and R. A. Terry. 1963. A two-stage technique for the in vitro digestion of forage crops. Grass Forage Sci. 18:104-111.

Van Soest, P. J., J. B. Robertson, and B. A. Lewis. 1991. Methods for dietary fiber, neutral detergent fiber, and non starch polysaccharides in relation to animal nutrition. J. Dairy Sci. 74:3583-3597. 